\title{
INDIRECT ACTIVE AND REACTIVE POWERS CONTROL OF DOUBLY FED INDUCTION GENERATOR FED BY THREE-LEVEL ADAPTIVE-NETWORK-BASED FUZZY INFERENCE SYSTEM - PULSE WIDTH MODULATION CONVERTER WITH A ROBUST METHOD BASED ON SUPER TWISTING ALGORITHMS
}

\begin{abstract}
Aim. This paper presents the minimization of reactive and active power ripples of doubly fed induction generators using super twisting algorithms and pulse width modulation based on neuro-fuzzy algorithms. Method. The main role of the indirect active and reactive power control is to regulate and control the reactive and active powers of doubly fed induction generators for variable speed dual-rotor wind power systems. The indirect field-oriented control is a classical control scheme and simple structure. Pulse width modulation based on an adaptive-network-based fuzzy inference system is a new modulation technique; characterized by a simple algorithm, which gives a good harmonic distortion compared to other techniques. Novelty. adaptive-network-based fuzzy inference system-pulse width modulation is proposed. Proposed modulation technique construction is based on traditional pulse width modulation and adaptive-network-based fuzzy inference system to obtain a robust modulation technique and reduces the harmonic distortion of stator current. We use in our study a $1.5 \mathrm{MW}$ doubly-fed induction generator integrated into a dual-rotor wind power system to reduce the torque, current, active power, and reactive power ripples. Results. As shown in the results figures using adaptive-network-based fuzzy inference system-pulse width modulation technique ameliorate effectiveness especially reduces the reactive power, torque, stator current, active power ripples, and minimizes harmonic distortion of current (0.08\%) compared to classical control. References 22, tables 4, figures 30.
\end{abstract}

Key words: doubly fed induction generators, pulse width modulation, neuro-fuzzy algorithms, indirect field-oriented control.

Мета У статті представлено мінімізацію пульсаиій реактивної та активної потужності асинхронних генераторів подвійного живлення з використанням алгоритмів суперскрутки та широтно-імпульсної модуляиї̈ на основі нейронечітких алгоритмів. Метод. Основна роль непрямого управління активною та реактивною потужністю полягає у керуванні та регулюванні реактивної та активної потужностей асинхронних генераторів з подвійним живленням для вітроенергетичних систем з подвійним ротором змінної швидкості. Непряме керування, орієнтоване на поле, - изе класична схема керування та проста структура. Широтно-імпульсна модуляиія, заснована на системі нечітких висновків на основі адаптивної мережі, є новим методом модуляиії; характеризується простим алгоритмом, який дає гарні гармонічні спотворення порівняно з іншими методами. Новизна. Пропонується адаптивна мережа на основі нечіткого висновку із широтно-імпульсною модуляцією. Запропонована побудова методу модуляції базується на традиційній широтноімпульсній модуляції та системі нечітких висновків на основі адаптивних мереж для отримання надійного методу модуляиї та зменшення гармонічних спотворень струму статора. У нашому дослідженні ми використовуємо асинхронний генератор з подвійним живленням потужністю 1,5 МВт, інтегрований у вітроенергетичну систему з подвійним ротором, щоб зменшити пульсаиії крутного моменту, струму, активної потужності та реактивної потужності. Результати. Як показано на рисунках з результатами, використання методу широтно-імпульсної модулячії на основі нечітких висновків системи адаптивних мереж покращує ефективність, особливо зменшує реактивну потужність, крутний момент, струм статора, пульсаиії активної потужності, та мінімізує гармонійне спотворення струму (0,08 \%) порівняно з класичним керуванням. Бібл. 22 , табл. 4 , рис. 30.

Ключові слова: асинхронні генератори 3 подвійним живленням, широтно-імпульсна модуляція, нейро-нечіткі алгоритми, непряме керування, оріснтоване на поле.

Introduction. In recent years, the traditional pulse width modulation (PWM) technique has drawn much attention from industry and research groups. The main advantages of the traditional PWM technique are its ease of implementation and simple algorithm compared to space vector modulation (SVM). But, this strategy gives more harmonic distortion of voltage and electromagnetic torque ripples. To overcome the drawbacks of the traditional PWM technique, a fuzzy PWM strategy has been presented $[1,2]$. In the fuzzy PWM strategy, the hysteresis comparators are replaced by the fuzzy controllers. This proposed strategy minimized the harmonic distortion of voltage compared to the classical PWM technique. In [3], the authors proposed the use of a PWM technique with a neural algorithm applied to the doubly fed induction generators (DFIG) drive, where the hysteresis comparators are replaced by neural algorithms. The simulation results show that the neural PWM technique is better than the classical PWM strategy in terms of reducing the harmonic distortion of voltage and torque ripples. In $[4,5]$, the fuzzy PWM strategy reduced the harmonic distortion of voltage compared to SVM and neural SVM techniques.

Recently, the Indirect Active and Reactive Powers Control (IARPC) method has been widely used for the control of AC machines. IARPC, based on classical PI controllers, has attracted a lot of research control machines for the last two decades. The IARPC method is one of the most used control techniques for wind power. This technique is simple algorithms. This technique is similar to field-oriented control (FOC). In [6], the authors proposed the use of an IARPC method with the neural SVM technique. In [7], an IARPC command based on a two-level fuzzy SVM technique has been proposed. The simulation results show that the IARPC control with fuzzy SVM strategy is better than traditional IARPC with classical SVM strategy in terms of minimizing the torque and active power ripples. In [8], a modified IARPC control scheme was proposed based on neuro-fuzzy algorithms with SVM strategy, where PI regulators were replaced by four controllers based on neuro-fuzzy 
algorithms. In [9], the IARPC control is the robust control compared to the direct active and reactive powers control (DARPC) of DFIG. IARPC control and three-level fuzzy SVM techniques are combined to reduce the torque, active and reactive power ripples of the DFIG [10].

The aim of this paper is the reduces the active and reactive power ripples and improve the effectiveness of the indirect active and reactive powers control using the proposed pulse width modulation technique and super twisting algorithms (STA) for doubly fed induction generators based dual-rotor wind turbine (DRWT) system under variable speed wind and also to minimize fluctuations in current, active power, torque, and reactive power.

In this work, the IARPC with STA controllers and three-level Adaptive-Network-based Fuzzy Inference System - Pulse Width Modulation (ANFIS-PWM) technique has been considered. The original contribution of this work is the application of the STA controllers and three-level ANFIS-PWM technique in the IARPC method with a DFIG-based DRWT system. The proposed method is compared with a classical IARPC control. The simulation results validate that the STA-IARPC with ANFIS-PWM technique reduced the torque, active and reactive powers ripples of the DFIG-based DRWT systems.

Three-level ANFIS-PWM technique. The classical PWM technique goal is to control the three-level inverter. In the three-level PWM technique, six hysteresis comparators were used. The PWM technique, which is designed to control the classical three-level converter, is shown in Fig. 1. PWM techniques are widely used as front-end converters in electronic drives. The advantage of a classical three-level PWM technique is a simple modulation scheme and easy to implement compared to the SVM strategy. Its application has been in electronic drives and controls. But this technique gives more harmonic distortion of voltage and electromagnetic torque of $\mathrm{AC}$ machine drive.

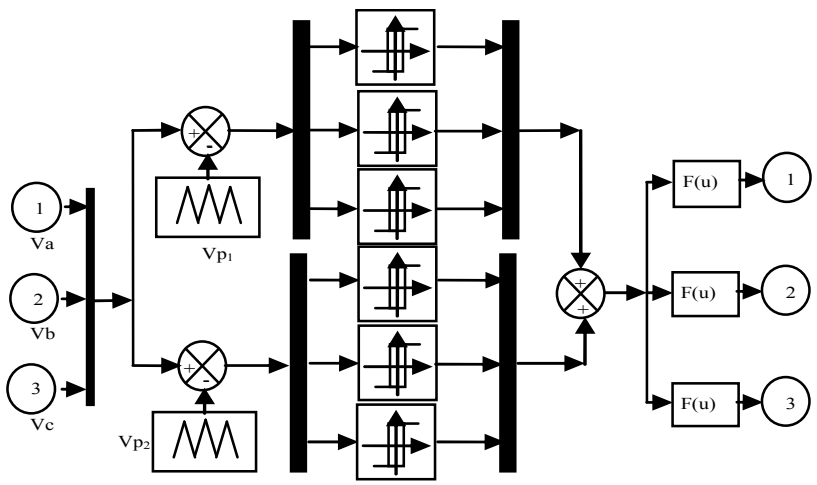

Fig. 1. The classical three-level PWM strategy

In order to improve the classical three-level PWM performances, complimentary use of the ANFIS algorithm is proposed. The principle of the three-level ANFIS-PWM technique is similar to the classical three-level PWM technique. The difference is using the ANFIS algorithm to replace the classical hysteresis comparators. Figure 2 shows the principle of the ANFIS-PWM strategy of a three-level inverter. Major advantages of proposed PWM techniques are as follows: minimized active and reactive powers ripples, a simple algorithm, and robust strategy. On the other hand, voltage space vectors generated by the three-level inverter in the coordinate system $\alpha-\beta$ are shown in Fig. 3, there are a totally of 27 vectors: 25 active vectors and three zero vectors in $\alpha-\beta$ coordinate systems. In this work, the modulation method with the use of 6 controllers from the same technique has been applied.

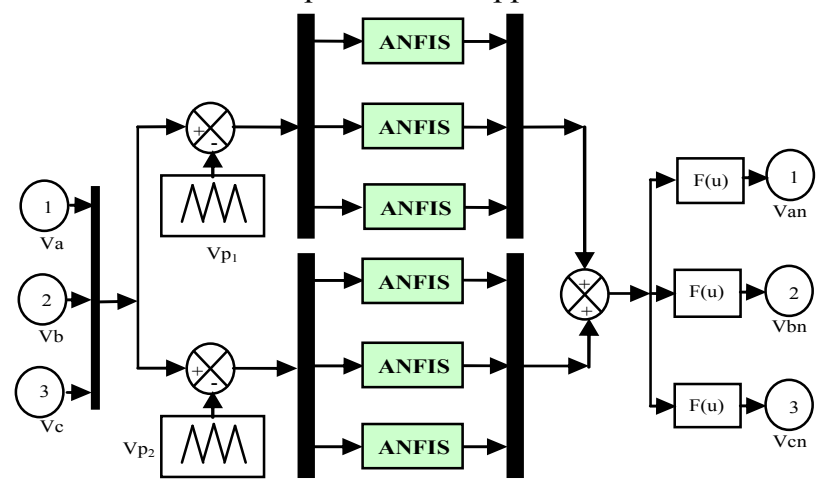

Fig. 2. The three-level ANFIS-PWM strategy

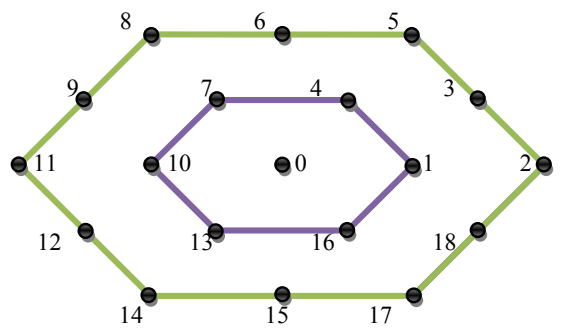

Fig. 3. Voltage space vectors generated by three-level inverter in the coordinate system $\alpha-\beta$

The schematic diagram of the ANFIS regulator is given in Fig. 4. Membership functions in triangular shape are shown in Fig. 5. The rule base of the ANFIS is shown in Table 1.

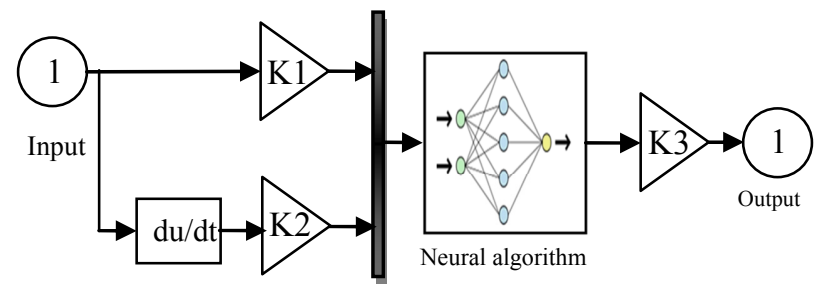

Fig. 4. Block diagram of the ANFIS algorithm

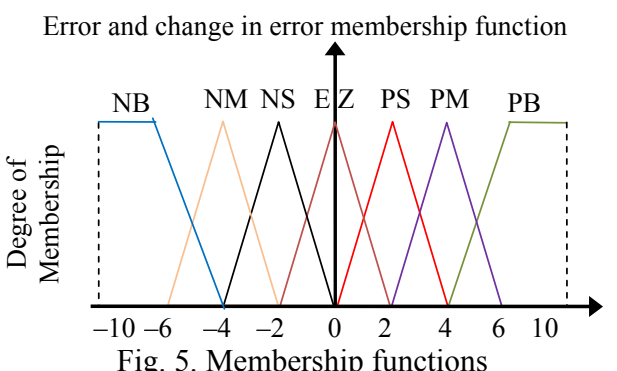

Table 1

ANFIS rules of the hysteresis comparators

\begin{tabular}{|c|c|c|c|c|c|c|c|}
\hline$\Delta e$ & NB & NM & NS & EZ & PS & PM & PB \\
\hline NB & NB & NB & NB & NB & NM & NS & EZ \\
\hline NM & NB & NB & NB & NM & NS & EZ & PS \\
\hline NS & NB & NB & NM & NS & EZ & PS & PM \\
\hline EZ & NB & NM & NS & EZ & PS & PM & PB \\
\hline PS & NM & NS & EZ & PS & PM & PB & PB \\
\hline PM & NS & EZ & PS & PM & PB & PB & PB \\
\hline PB & EZ & PS & PM & PB & PB & PB & PB \\
\hline
\end{tabular}


ANFIS algorithms were originally introduced in 1993 [11], the advantage of an ANFIS algorithm is a simple method and robust. This regulator has combined the advantages of the fuzzy and neural controllers. In order to make the ANFIS algorithm, we used the conventional neural network with Conjugate Gradiant with Beale-Powell Restarts algorithm. In MATLAB software, traincgb is the word we use to accomplish this algorithm.

The schematic diagram of the neural regulator of the ANFIS algorithm is shown in Fig. 6.

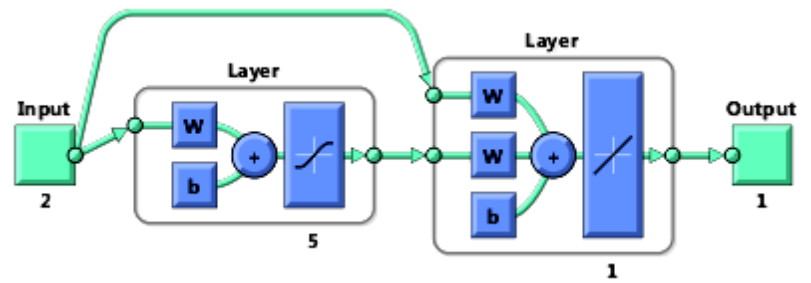

Fig. 6. Schematic diagram of the neural regulator

The neural controllers consist of an input layer, two hidden layers, and an output layer. The parameters of the neural regulator for the ANFIS algorithms are shown in Table 2.

Table 2

\begin{tabular}{|l|c|}
\hline \multicolumn{1}{|c|}{ Parameters } & \multicolumn{1}{c|}{ Values } \\
\hline Training & $\begin{array}{c}\text { Conjugate Gradiant with Beale- } \\
\text { Powell Restarts (traincgb) }\end{array}$ \\
\hline TrainParam.Lr & 0.05 \\
\hline TrainParam.goal & 0 \\
\hline Performances & Mean Squard Error (mse) \\
\hline TrainParam.mu & 0.8 \\
\hline Number of input layer & 1 \\
\hline $\begin{array}{l}\text { Number of neurons for input } \\
\text { layer }\end{array}$ & 2 \\
\hline TrainParam.eposh & 300 \\
\hline Number of output layer & 1 \\
\hline $\begin{array}{l}\text { Number of neurons for output } \\
\text { layer }\end{array}$ & 1 \\
\hline TrainParam.show & 50 \\
\hline derivative & Default (default deriv) \\
\hline Number of hidden layer & 1 \\
\hline $\begin{array}{l}\text { Number of neurons for } \\
\text { hidden layer }\end{array}$ & 5 \\
\hline $\begin{array}{l}\text { Coeff of acceleration of } \\
\text { convergence (mc) }\end{array}$ & 0.8 \\
\hline Functions of activation & Tensing, Purling, traincgb \\
\hline
\end{tabular}

Figure 7 shows the neural network training performance of the ANFIS algorithm of the PWM technique by using the conjugate gradiant with the BealePowell restarts algorithm.

IARPC strategy. The IARPC algorithm was originally introduced in the 1970s [12]. The IARPC strategy goal is to control the reactive and active powers of the DFIG-based DRWT systems (Fig. 8)

$$
\begin{aligned}
& \psi_{q s}=0, \quad \psi_{d s}=\psi_{s}, \\
& V_{q s}=0, \quad V_{d s}=\omega_{s} \psi_{s} . \\
& \left\{\begin{array}{l}
I_{d s}=-\frac{M}{L_{s}} I_{d r}+\frac{\psi_{s}}{L_{s}} \\
I_{q s}=-\frac{M}{L_{s}} I_{q r} .
\end{array}\right.
\end{aligned}
$$

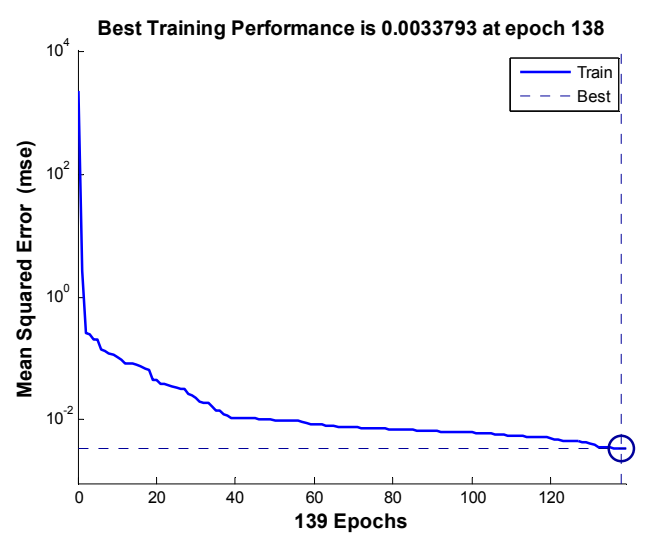

Fig. 7. Training performance

The expression of the rotor voltages are:

$$
\left\{\begin{array}{l}
V_{d r}=R_{r} \cdot I_{d r}-w_{r} \cdot\left(L_{r}-\frac{M^{2}}{L_{s}}\right) \cdot I_{q r} ; \\
V_{q r}=R_{r} \cdot I_{q r}+w_{r} \cdot\left(L_{r}-\frac{M^{2}}{L_{s}}\right) \cdot I_{d r}+g \cdot \frac{M \cdot V_{s}}{L_{s}} .
\end{array}\right.
$$

The expression of the rotor fluxes and powers becomes:

$$
\begin{aligned}
& \left\{\begin{array}{l}
\Psi_{d r}=\left(L_{r}-\frac{M^{2}}{L_{S}}\right) I_{d r}+\frac{M \cdot V_{s}}{L_{s} \cdot w_{s}} ; \\
\Psi_{q r}=\left(L_{r}-\frac{M^{2}}{L_{S}}\right) I_{q r} .
\end{array}\right. \\
& \left\{\begin{array}{l}
P_{S}=-\frac{3}{2} \frac{\omega_{s} \psi_{s} M}{L_{s}} I_{q r} ; \\
Q_{S}=-\frac{3}{2}\left(\frac{\omega_{s} \psi_{s} M}{L_{s}} I_{d r}-\frac{\omega_{s} \psi_{s}^{2}}{L_{s}}\right)
\end{array}\right.
\end{aligned}
$$

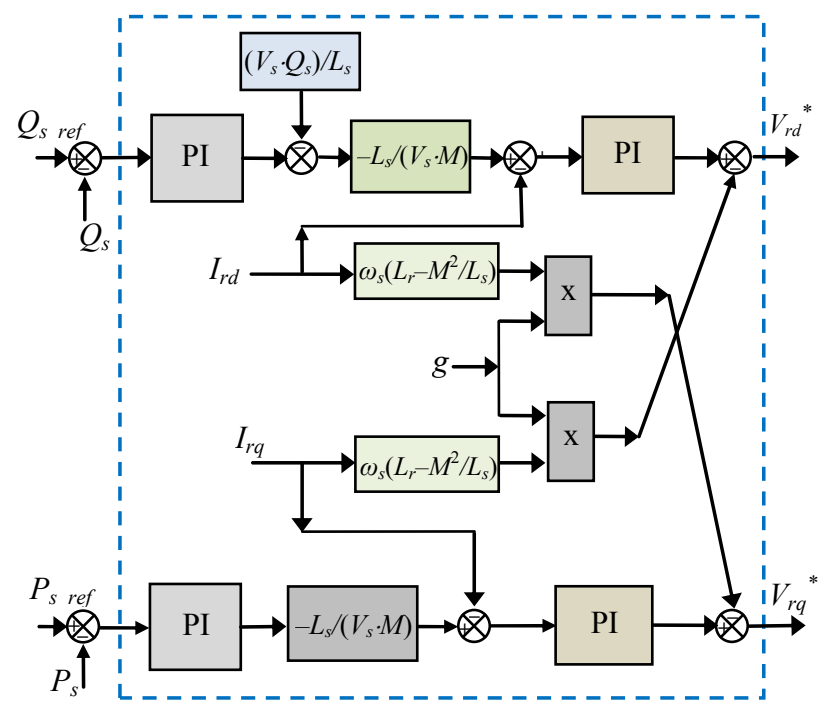

Fig. 8. Structure of the IARPC strategy

The IARPC strategy of a three-phase DFIG-based DRWT system with PWM technique is shown in Fig. 9.

STA-IARPC method with ANFIS-PWM technique. The main objective of using the STA- IARPC method is to develop a robust control of active and reactive powers of the DFIG-based DRWT system. In our 


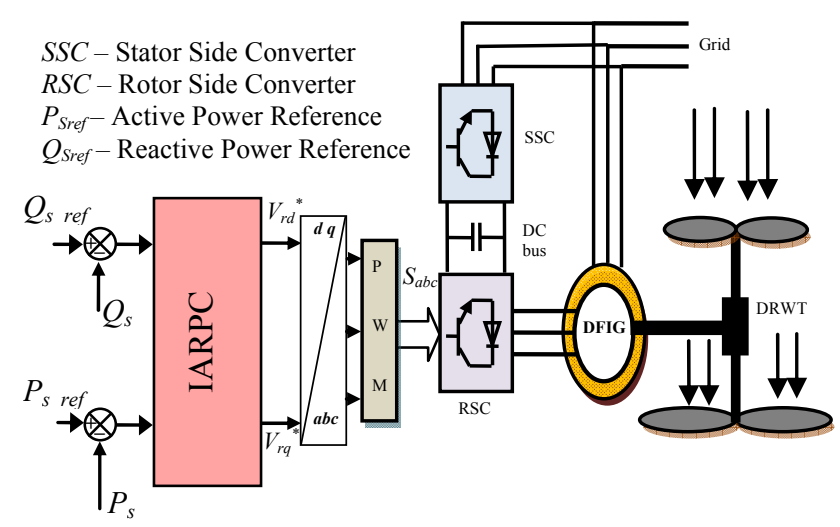

Fig. 9. IARPC strategy of the DFIG

system, the reactive and active powers are respectively controlled by $V_{d r}$ and $V_{q r}$.

In the aim to design an advanced IARPC method with very small active and reactive powers undulations and without harmonic distortion of current, in our work, we suggest employing a new IARPC method based on a three-level ANFIS-PWM technique and STA algorithms for a DFIG-based DRWT system. This is for essential objects, including minimizing torque ripple and improving active and reactive power quality provided to the grid.

Since the STA algorithm generalizes the basic second-order sliding mode control design by integrating second-order derivatives of the sliding variable. This strategy is proposed by Levant in 1993 [13]. The STA algorithms have gained importance in the recent past due to their fast response and superior control characteristics. The STA algorithm maintains the advantages of the classical sliding mode control. This algorithm eliminated the phenomena of chattering compared to the classical sliding mode control strategy. In [14], the authors suggest the use of a direct torque and flux control (DTFC) with the STA algorithm employed to DFIG drive. A neural STA regulator was designed to improve the DTFC control of DFIG [15]. Fuzzy controller and STA algorithm are combined to reduce the torque ripple of DFIG controlled by DTFC control [16]. ANFIS-STA algorithm is proposed to reduce the harmonic distortion and electromagnetic torque ripple of DFIG [17]. In [18], direct field-oriented control (DFOC) was proposed based on the STA algorithm with the SVM strategy. The experimental results show that the DFOC with the STA algorithm is the robust control compared to the classical DFOC strategy. In [19], direct reactive and active power control (DRAPC) strategy based on the STA algorithm has been proposed. In [20], a modified DRAPC strategy was proposed based on the neural STA algorithm with a two-level SVM technique, where the PI regulators are replaced by the neural STA algorithms. However, active and reactive power ripples are considered the main drawback of the conventional DRAPC method. In [21], the authors proposed the use of a DRAPC with an ANFIS-STA algorithm applied to the DFIG-based wind turbine.

The output signal from the STA regulator is comparable with the control signal obtained from linear
PI regulators. The mathematical model of the STA regulator can be written as follows [22]:

$$
\left\{\begin{array}{c}
u=K_{p}|S|^{r} \operatorname{sgn}(S)+u_{1} \\
\frac{d u_{1}}{d t}=K_{i} \operatorname{sgn}(S) .
\end{array}\right.
$$

where $S$ is the switching function determined for the STA regulator; $r$ is the exponent defined for the STA regulator; $K_{i}$ and $K_{p}$ are the coefficients of the integral and proportional parts of the STA regulator, respectively.

The schematic diagram of the STA regulator is presented in Fig. 10.

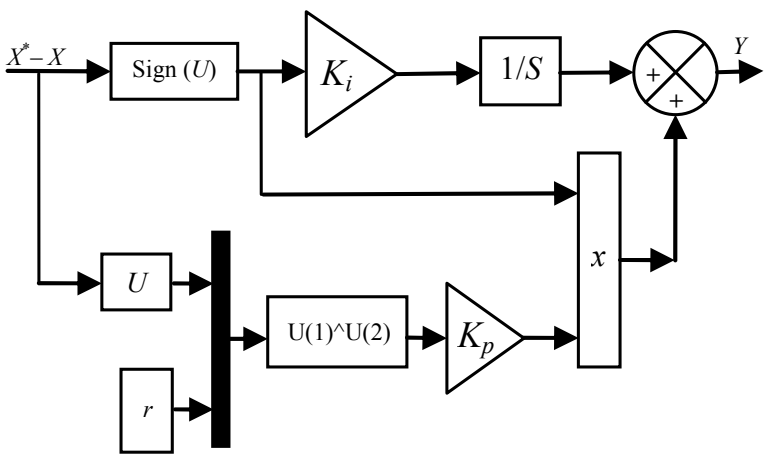

Fig. 10. Schematic diagram of the STA regulator

Compared with the traditional IARPC strategy, the STA-IVC with three-level ANFIS-PWM technique ensures diverse advantages such as the reduction of torque ripple, harmonic distortion of current/voltage, active power ripples. Furthermore, it keeps the robust control, a simple method of control with almost no changes in the basic structure of the IARPC strategy. The IARPC strategy of a three-phase DFIG-based DRWT system with the application of the classical STA regulators and ANFIS-PWM technique is shown in Fig. 11.

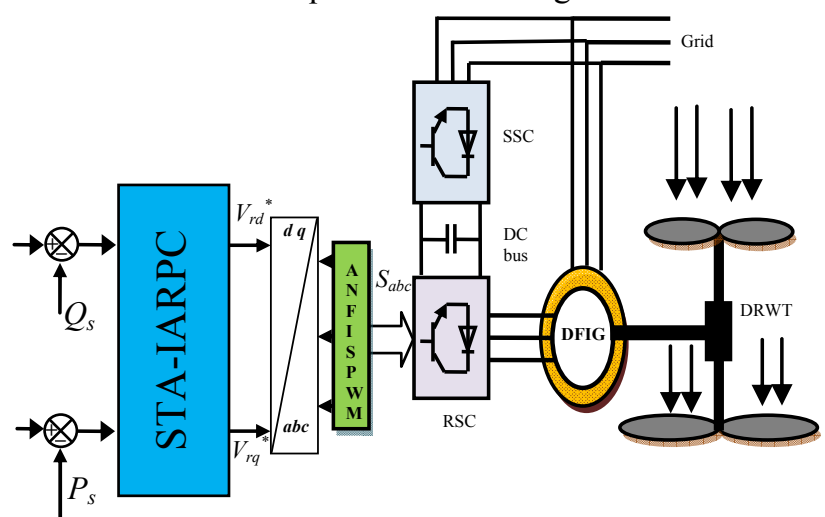

Fig. 11. IARPC strategy of the DFIG with the application of STA algorithm and ANFIS-PWM technique

In this control strategy, the reactive and active powers are controlled by the four STA regulators (Fig. 12).

Simulation results. The DFIG used in this work is a 1.5 MW, 380/690 V, $50 \mathrm{~Hz}$, a machine whose nominal parameters are reported in Table 3. Both control schemes classical IARPC and proposed control are simulated and compared in terms of reference tracking, robustness against machine parameter variations, and current harmonics distortion. The simulations are lead with the MATLAB software. 


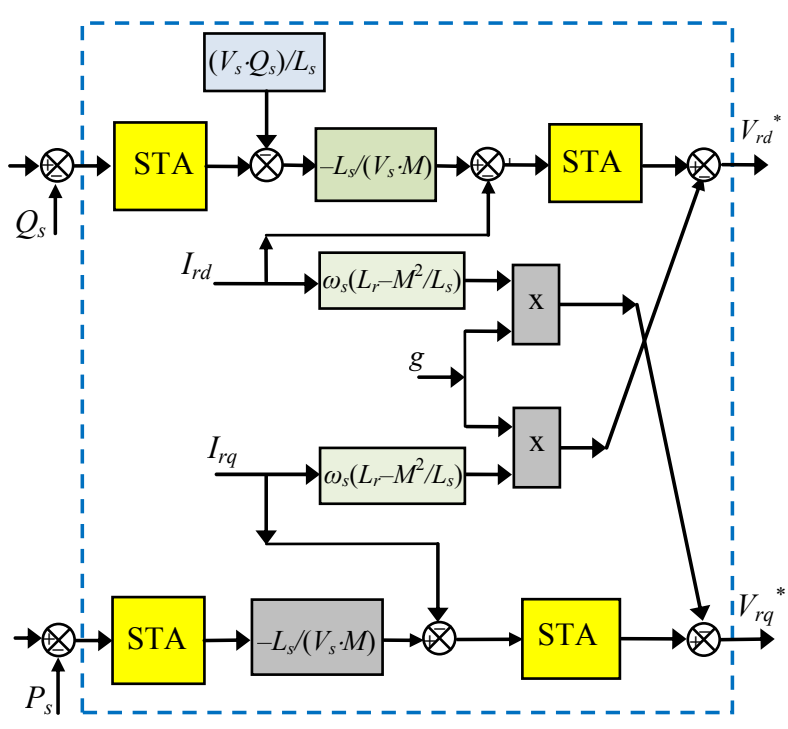

Fig. 12. Structure of the STA-IARPC strategy

Table 3

Parameters of the simulated DFIG

\begin{tabular}{|c|c|}
\hline$P_{n}, \mathrm{MW}$ & 1.5 \\
\hline$V_{n}, \mathrm{~V}$ & 380 \\
\hline$p$ & 2 \\
\hline$R_{s}, \Omega$ & 0.012 \\
\hline$R_{r}, \Omega$ & 0.021 \\
\hline$L_{s}, \mathrm{H}$ & 0.0137 \\
\hline$L_{r}, \mathrm{H}$ & 0.0136 \\
\hline$L_{m}, \mathrm{H}$ & 0.0135 \\
\hline$J, \mathrm{~kg} \cdot \mathrm{m}^{2}$ & 1000 \\
\hline$f_{r}, \mathrm{Nm} \cdot \mathrm{s} / \mathrm{rad}$ & 0.0024 \\
\hline$f, \mathrm{~Hz}$ & 50 \\
\hline
\end{tabular}

First test. The objective of this test is to study the behavior of both IARPC strategies while the DFIG's speed is considered maintained at its nominal value. Figures 15-18 show the obtained simulation results. The simulation waveforms of the reference and measured active power of the DFIG are shown in Fig. 15. To compare the performance of the proposed control with the performance of the classical IARPC command with the traditional PWM technique. At the load condition, the reactive power becomes identified as the load active power. On the other hand, these waveforms demonstrate that the analyzed STA algorithm allows obtaining control signal with the waveforms similar to the output signals from linear PI regulators. It can be seen that the active power is controlled properly at the given reference value.

The trajectory of the estimated of reactive power for the proposed control schemes is shown in Fig. 16. It can be stated that the reactive power is controlled properly at the nominal value.

The simulation waveform of all electromagnetic torque of the DFIG for the considered control system is shown in Fig. 17. The amplitude of the electromagnetic torque depend on the value of the load active power.

The simulation waveform of all stator phase currents of DFIG for the considered control system is shown in Fig. 18. The amplitude of the stator currents depends on the state of the drive system and the value of the load active and reactive powers. On the other hand, Fig. 13, 14 show the harmonic spectrum of the stator current of the
DFIG-based DRWT system for the classical IARPC and proposed control strategy. It can be observed that the THD value is minimized for a proposed control $(0.08 \%)$ when compared to classical IARPC with a three-level PWM strategy $(0.47 \%)$.

The response time of the torque, reactive and active powers for both methods are shown in Table 4 . It can be stated that the proposed control minimized more the response time of the electromagnetic torque, reactive and active powers compared to classical IARPC with a threelevel PWM strategy.

Table 4

\begin{tabular}{|}
\begin{tabular}{|c|c|c|c|}
\hline \multirow{2}{*}{ Comparative analysis of response time } \\
\cline { 2 - 4 } & Active power & Torque & Reactive power \\
\hline IARPC-PWM & $0.135 \mathrm{~s}$ & $0.135 \mathrm{~s}$ & $0.122 \mathrm{~s}$ \\
\hline Proposed control & $3 \mathrm{~ms}$ & $3 \mathrm{~ms}$ & $3.7 \mathrm{~ms}$ \\
\hline
\end{tabular}
\end{tabular}

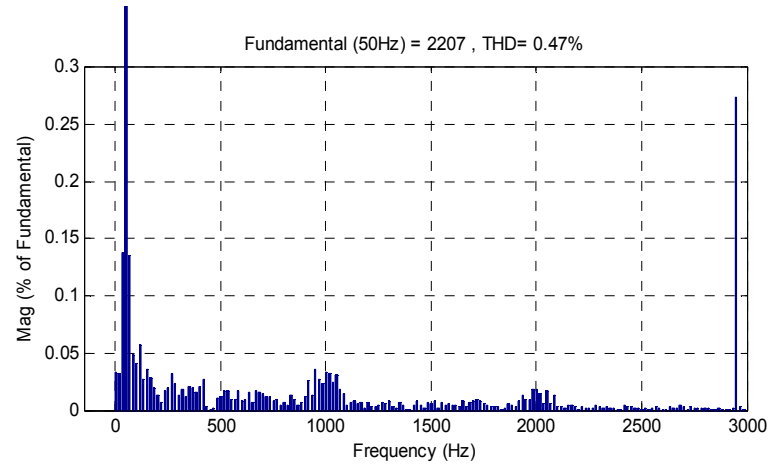

Fig. 13. THD of the IARPC control

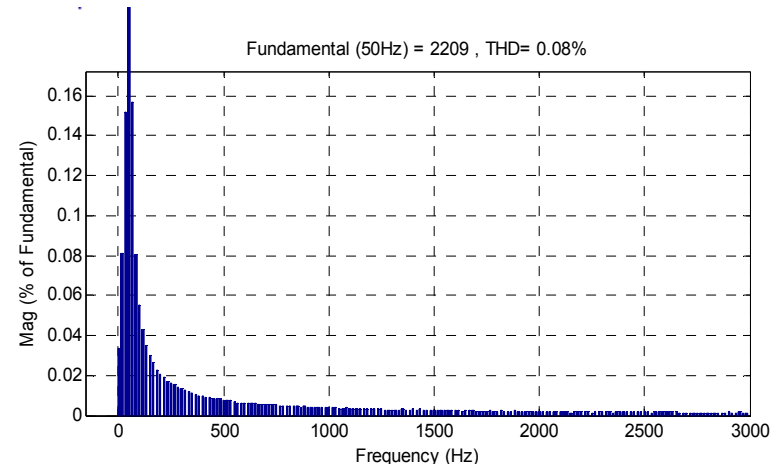

Fig. 14. THD of the STA-IARPC-ANFIS-PWM method

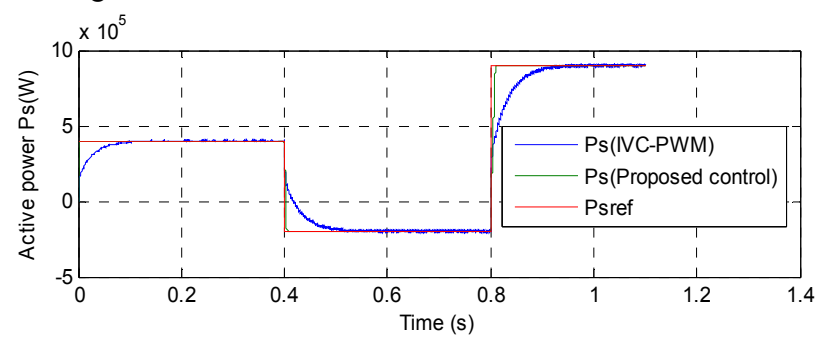

Fig. 15. Stator active power $P_{s}$

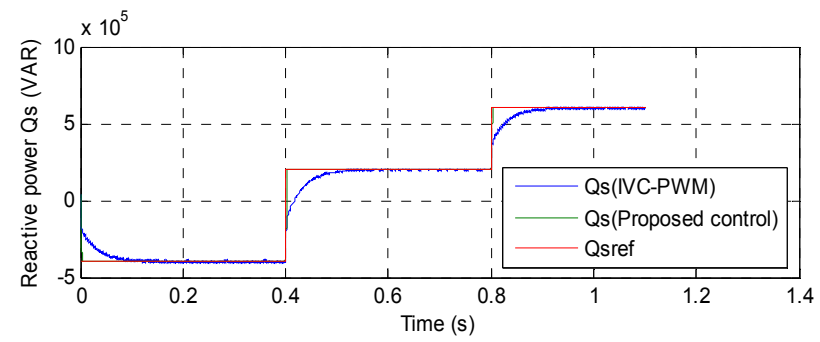

Fig. 16. Stator reactive power $Q_{s}$ 


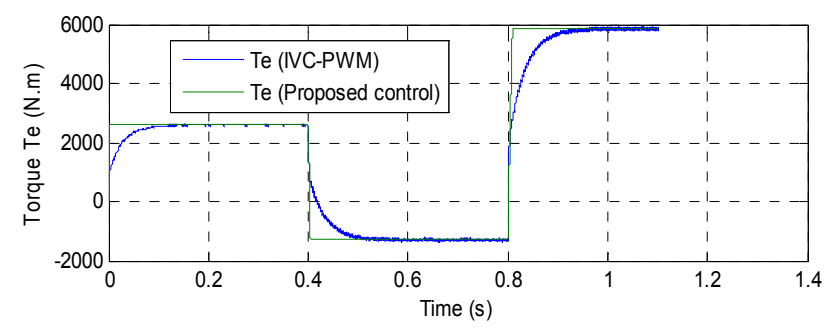

Fig. 17. Torque $T_{e}$

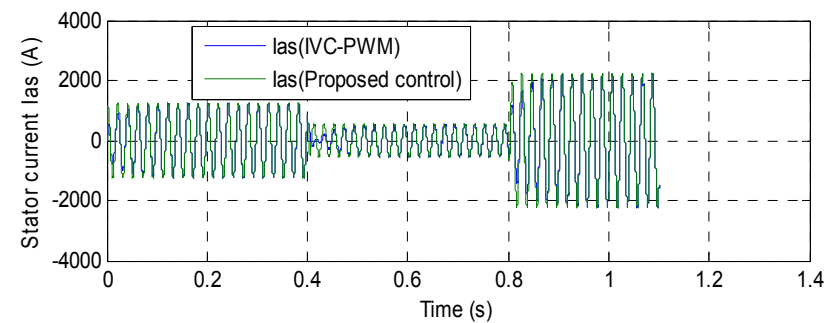

Fig. 18. Stator current $I_{a s}$

The zoom of the active power, reactive power, torque, and stator current of the DFIG-based DRWT system is shown in Fig. 19-22, respectively. As can be seen, the proposed control minimized the ripples in torque, current, active and reactive powers compared to the classical IARPC control.

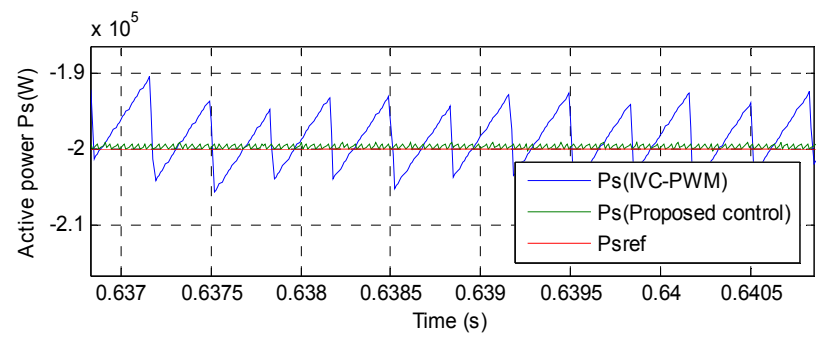

Fig. 19. Zoom in the active power $P_{s}$

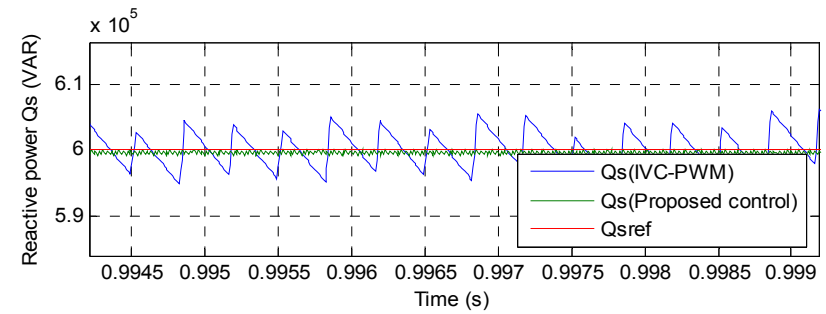

Fig. 20. Zoom in the reactive power $Q_{s}$

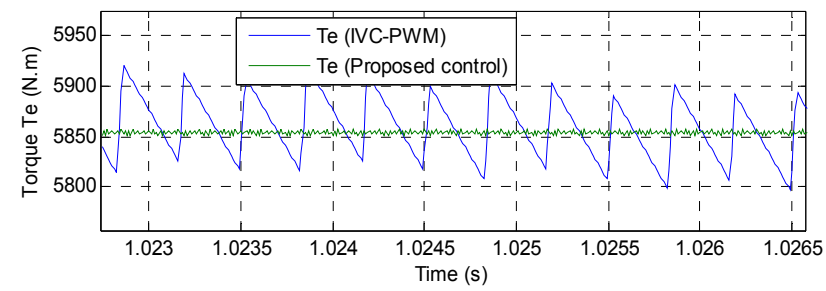

Fig. 21. Zoom in the torque $T_{e}$

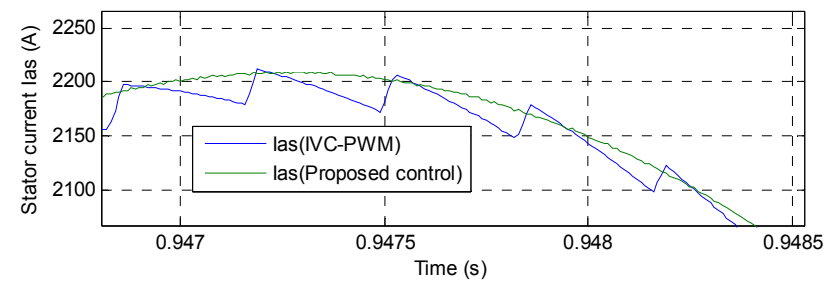

Fig. 22. Zoom in the current $I_{a s}$
Second test. For analyzing the robustness of the used proposed strategy, the DFIG parameters have been intentionally changed such as the values of the stator and the rotor resistances $R_{s}$ and $R_{r}$ are doubled and the values of inductances $L_{s}, L_{r}$ and $M$ are divided by 2 . The DFIG is running at its nominal speed. Simulation results are presented in Fig. 23-27. As shown by these Figures, we notice that parameter variations of the DFIG increase slightly the time-response of the proposed strategy. On the other, hand these results show these variations present a clear effect on the torque, reactive power, stator current, and active power curves and that the effect appears more important for the classical IARPC than that with the designed strategy (Fig. 28-30). According to the simulation results in Fig. 23, 24, the THD value of the output stator current is about $2.06 \%$ and $0.11 \%$ for classical IARPC and proposed strategy, respectively. Thus it can be concluded that the proposed strategy is more robust than the classical IARPC control.

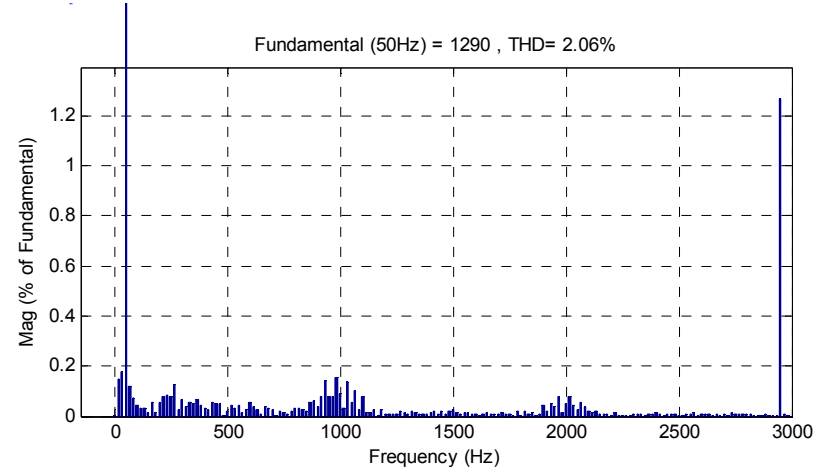

Fig. 23. THD of the IARPC control

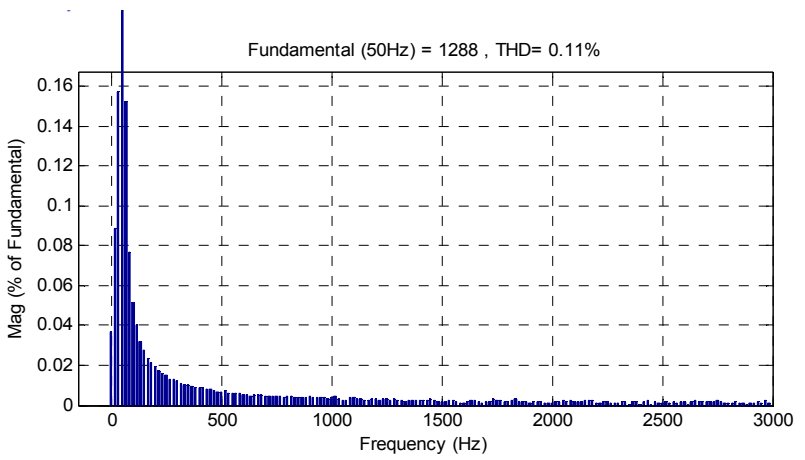

Fig. 24. THD of the STA-IARPC-ANFIS-PWM control

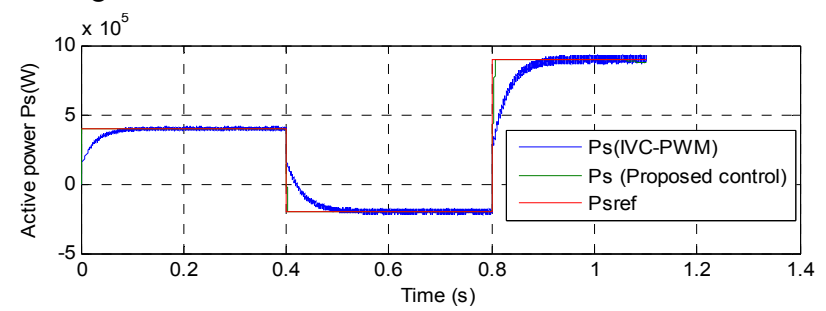

Fig. 25. Active power $P_{s}$

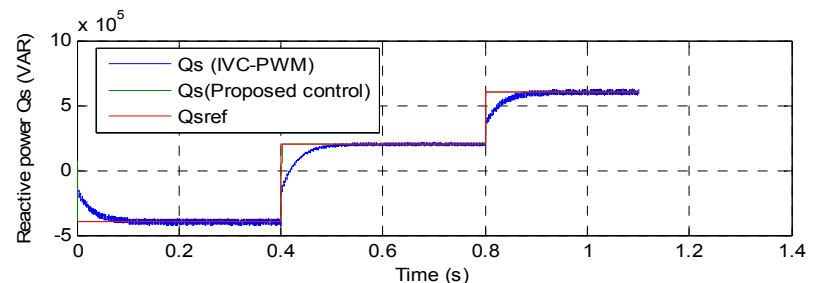

Fig. 26. Reactive power $Q_{s}$ 


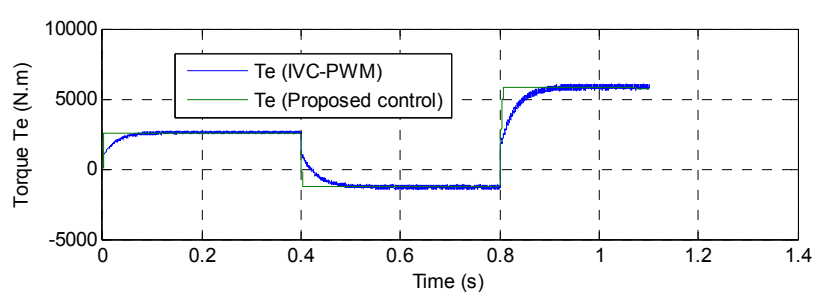

Fig. 27. Torque $T_{e}$

The zoom of the active power, reactive power, and torque of the DFIG-based DRWT system is shown in Fig. 28-30, respectively. As can be seen, the designed strategy minimized the ripples in torque, active and reactive powers compared to the traditional IARPC strategy.

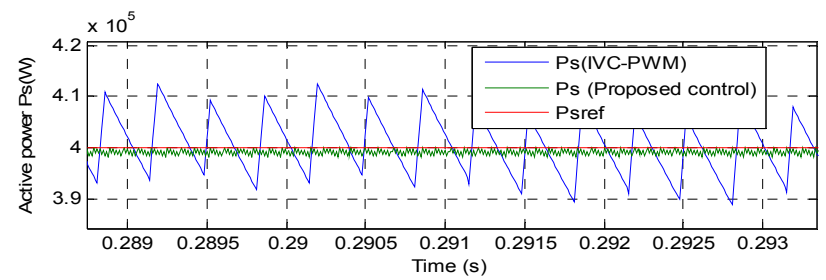

Fig. 28. Zoom in the active power

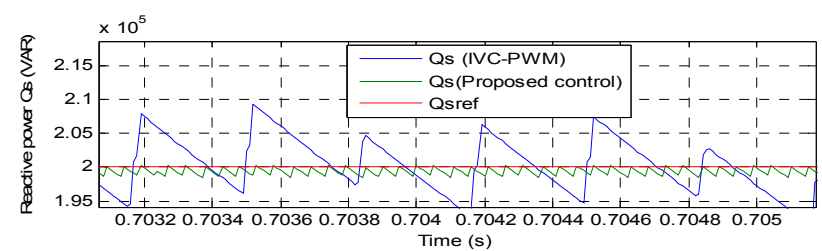

Fig. 29. Zoom in the reactive power $Q_{s}$

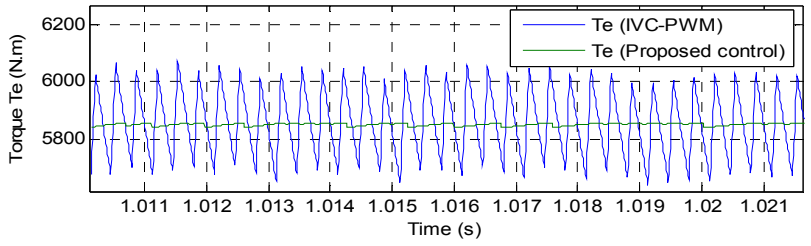

Fig. 30. Zoom in the torque $T_{e}$

\section{Conclusion.}

In this work, the super-twisting sliding mode called super twisting algorithms (STA) is developed and applied to three-phase doubly fed induction generators (DFIG) based dual-rotor wind turbine (DRWT) systems using three-level adaptive-network-based fuzzy inference system - pulse width modulation (ANFIS-PWM) techniques. The performance of the super twisting algorithms-the indirect active and reactive powers control (STA-IARPC) control with three-level ANFIS-PWM techniques is evaluated and compared with traditional IARPC and the regular STAIARPC methods in the context of power control of the DFIG for linear loads. Simulation results show that the STA-IARPC with three-level ANFIS-PWM technique reduced the active and reactive powers ripples compared to the traditional IARPC strategy. Moreover, the STA-IARPC strategy with three-level ANFIS-PWM techniques has faster dynamic responses compared to the traditional IARPC strategy. Also, STA-IARPC with three-level ANFIS-PWM technique reduced the harmonic distortion of stator current compared to the classical IARPC strategy. Detailed simulation results using MATLAB software are presented. Basing on all these results it can be concluded that robust strategy as the STA-IARPC strategy with threelevel ANFIS-PWM technique can be a very attractive solution for devices using DFIG such as DRWT systems.

Conflict of interest. The authors declare that they have no conflicts of interest.

\section{REFERENCES}

1. Benbouhenni H. FPWM technique based converter for IM drives. Acta Electrotechnica et Informatica, 2019, vol. 19, no. 1, pp. 32-41. doi: https://doi.org/10.15546/aeei-2019-0005.

2. Benbouhenni H., Boudjema Z., Belaidi A. DFIG-based WT system using FPWM inverter. International Journal of Smart Grid, 2018, vol. 2, no. 3, pp. 142-154. Available at: https://www.ijsmartgrid.org/index.php/ijsmartgridnew/article/vi ew/16 (accessed 14 March 2021).

3. Benbouhenni H. Sliding mode with neural network regulator for DFIG using two-level NPWM strategy. Iranian Journal of Electrical \& Electronic Engineering, 2019, vol. 15, no. 3, pp. 411-419. doi: http://dx.doi.org/10.22068/IJEEE.15.3.411.

4. Benbouhenni H. A comparison study between fuzzy PWM and SVM inverter in NSMC control of stator active and reactive power control of a DFIG based wind turbine systems. International Journal of Applied Power Engineering, 2019, vol. 8, no. 1, pp. 78-92. doi: https://doi.org/10.11591/ijape.v8.i1.pp78-92. 5. Benbouhenni H. Comparison study between FPWM and NSVM inverter in neuro-sliding mode control of reactive and active power control of a DFIG-based wind energy. Majlesi Journal of Energy Management, 2017, vol. 6, no. 4, pp. 15-23. Available

http://journals.iaumajlesi.ac.ir/em/index/index.php/em/article/vi ew/338 (accessed 14 March 2021).

6. Benbouhenni H., Boudjema Z., Belaidi A. A comparative study between four-level NSVM and three-level NSVM technique for a DFIG-based WECSs controlled by indirect vector control. Carpathian Journal of Electronic and Computer Engineering, 2018, vol. 11, no. 2, pp. 13-19. doi: https://doi.org/10.2478/cjece-2018-0012.

7. Benbouhenni H., Boudjema Z., Belaidi A. Indirect vector control of a DFIG supplied by a two-level FSVM inverter for wind turbine system. Majlesi Journal of Electrical Engineering, 2019, vol. 13, no. 1, pp. 45-54. Available at: http://mjee.iaumajlesi.ac.ir/index/index.php/ee/article/view/2693 (accessed 14 March 2021).

8. Amrane F., Chaiba A. A novel direct power control for gridconnected doubly fed induction generator based on hybrid artificial intelligent control with space vector modulation. Revue Roumaine des sciences techniques. Série Électrotechnique et Énergétique, 2016, vol. 61, no. 3, pp. 263-268. Available at: http://revue.elth.pub.ro/index.php?action=details\&id=597 (accessed 12 May 2020).

9. Benbouhenni H. Comparative study between different vector control methods applied to DFIG wind turbines. Majlesi Journal of Mechatronic Systems, 2018, vol. 6, no. 4, pp. 15-23. Available at: http://journals.iaumajlesi.ac.ir/ms/index/index.php/ms/article/view/3 $\underline{82}$ (accessed 14 March 2021).

10. Benbouhenni H., Boudjema Z., Belaidi A. Using threelevel Fuzzy space vector modulation method to improve indirect vector control strategy of a DFIG based wind energy conversion systems. International Journal of Smart Grid, 2018, vol. 2, no. 3, pp. 155-171. Available at: https://www.ijsmartgrid.org/index.php/ijsmartgridnew/article/ view/15 (accessed 14 March 2021).

11. Jang J.-S.R. ANFIS: adaptive-network-based fuzzy inference system. IEEE Transactions on Systems, Man, and Cybernetics, 1993, vol. 23, no. 3, pp. 665-685. doi: https://doi.org/10.1109/21.256541.

12. Benbouhenni $\mathrm{H}$. Intelligence indirect vector control of a DFIG based wind turbines. Majlesi Journal of Electrical 
Engineering, 2019, vol. 13, no. 3, pp. 27-35. Available at: http://mjee.iaumajlesi.ac.ir/index/index.php/ee/article/view/2972 (accessed 14 March 2021).

13. Levant A. Sliding order and sliding accuracy in sliding mode control. International Journal of Control, 1993, vol. 58, no. 6, pp. 1247-1263. https://doi.org/10.1080/00207179308923053.

14. Boudjema Z., Taleb R., Djerriri Y., Yahdou A. A novel direct torque control using second order continuous sliding mode of a doubly fed induction generator for a wind energy conversion system. Turkish Journal of Electrical Engineering \& Computer Sciences, 2017, vol. 25, no.2, pp. 965-975. doi: https://doi.org/10.3906/elk-1510-89.

15. Benbouhenni $\mathrm{H}$. Rotor flux and torque ripples minimization for direct torque control of DFIG by NSTSM algorithm. Majlesi Journal of Energy Management, 2018, vol. 7, no. 3, pp. 1-9. Available at: http://journals.iaumajlesi.ac.ir/em/index/index.php/em/article/vi

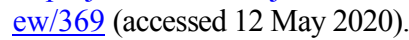

16. Benbouhenni H. Stator current and rotor flux ripples reduction of DTC DFIG drive using FSTSMC algorithm. International Journal of Smart Grid, 2019, vol. 3, no. 4, pp. 226-234. Available https://www.ijsmartgrid.org/index.php/ijsmartgridnew/article/vi ew/82 (accessed 14 March 2021).

17. Benbouhenni H. Utilization of an ANFIS-STSM algorithm to minimize total harmonic distortion. International Journal of Smart Grid, 2020, vol. 4, no. 2, pp. 56-67. Available at: https://www.ijsmartgrid.org/index.php/ijsmartgridnew/article/vi ew/98 (accessed 14 March 2021).

18. Listwan J. Application of super-twisting sliding mode controllers in direct field-oriented control system of six-phase induction motor: experimental studies. Power Electronics and Drives, 2018, vol. 3, no. 1, pp. 23-34. doi: https://doi.org/10.2478/pead-2018-0013.

19. Bouyekni A., Taleb R., Boudjema Z., Kahal H. A secondorder continuous sliding mode based on DFIG for wind-turbinedriven DFIG. Elektrotehniški vestnik, 2018, vol. 85, no. 1-2, pp. 29-36. https://ev.fe.uni-lj.si/1-2-2018/Bouyekni.pdf.
20. Benbouhenni H., Boudjema Z., Belaidi A. Direct power control with NSTSM algorithm for DFIG using SVPWM technique. Iranian Journal of Electrical \& Electronic Engineering, 2021, vol. 17, no. 1, pp. 1-11. doi: http://dx.doi.org/10.22068/IJEEE.17.1.1518.

21. Benbouhenni H., Boudjema Z., Belaidi A. DPC based on ANFIS super-twisting sliding mode algorithm of a doubly-fed induction generator for wind energy system. Journal Européen des Systèmes Automatisés, 2020, vol. 53, no. 1, pp. 69-80. doi: https://doi.org/10.18280/jesa.530109.

22. Tayebi-Haghighi S., Piltan F., Kim J.-M. Robust Composite High-Order Super-Twisting Sliding Mode Control of Robot Manipulators. Robotics, 2018, vol. 7, no. 1, p. 13. https://doi.org/10.3390/robotics7010013.

Received 22.04.2021

Accepted 31.05.2021

Published 27.08.2021

Habib Benbouhenni ${ }^{1}$, Doctor of Electrical Engineering, Ahmed Driss ${ }^{2}$, Doctor of Electrical Engineering,

Soufiane Lemdani ${ }^{3}$, Doctor of Electrical Engineering,

${ }^{1}$ Department of Electrical \& Electronics Engineering,

Nisantasi University, Istanbul, Turkey,

e-mail: habib.benbouenni@nisantasi.edu.tr (Corresponding author)

${ }^{2}$ Department of Electrical Engineering,

Ecole National Polytechnique School of Oran Maurice Audin,

LAAS Research Laboratory,

Oran, Algeria,

ENP-MA, Oran, Algeria,

e-mail: drisahmed82@yahoo.com

${ }^{3}$ Department of Electrical Engineering,

University of Science and Technology of Oran-Mohamed-

Boudiaf, Oran, Algeria,

e-mail: lamdaniso@yahoo.fr

\section{How to cite this article:}

Benbouhenni H., Driss A., Lamdani S. Indirect active and reactive powers control of doubly fed induction generator fed by threelevel adaptive-network-based fuzzy inference system - pulse width modulation converter with a robust method based on super twisting algorithms. Electrical Engineering \& Electromechanics, 2021, no. 4, pp. 31-38. doi: https://doi.org/10.20998/2074272X.2021.4.04. 